\title{
RADIOCARBON IN SEAWATER AT RADIOACTIVE WASTE DUMPING SITES IN THE NORTHEAST ATLANTIC AND NORTHWEST PACIFIC
}

\author{
P P Povinec $^{1} \bullet \mathrm{A} \mathrm{J} \mathrm{T} \mathrm{Jull}^{2} \bullet \mathrm{G} \mathrm{S}$ Burr $^{2}$ \\ ABSTRACT. Radiocarbon has been an important constituent of radioactive wastes dumped in the open ocean and marginal \\ seas as well as wastes released from nuclear reprocessing plants. Therefore, in some regions these sources could have a greater \\ impact on ${ }^{14} \mathrm{C}$ concentration in seawater than global fallout. The high analytical sensitivity of ${ }^{14} \mathrm{C}$ measurement by accelerator \\ mass spectrometry (AMS) allows even tracer amounts of ${ }^{14} \mathrm{C}$ to be found in seawater at radioactive waste dumping sites and \\ their comparison with the global distribution of this radionuclide. Data on measurements of ${ }^{14} \mathrm{C}$ in samples taken at former \\ dumping sites in the northeast Atlantic and northwest Pacific Oceans and in the open ocean are discussed and compared with \\ other anthropogenic radionuclides, namely ${ }^{3} \mathrm{H}$. Small increases in ${ }^{14} \mathrm{C}$ concentrations observed in some bottom and surface \\ seawater samples collected at the Northwest Pacific Ocean dumping sites require further ${ }^{14} \mathrm{C}$ analyses before final conclusions \\ can be made on possible leakages from dumped radioactive wastes.
}

\section{INTRODUCTION}

According to information available from the IAEA (1999) on radioactive waste dumping in the world's oceans and seas, the highest total activities of dumped wastes were $45 \mathrm{PBq}$ (all data at the time of dumping) in the Atlantic Ocean, $38 \mathrm{PBq}$ in the Arctic Ocean and 1.4 PBq in the Pacific Ocean. Mainly low-level solid wastes (below $5 \times 10^{-5} \mathrm{TBq} / \mathrm{kg}$ for alpha emitters, below $2 \times 10^{-2} \mathrm{TBq} / \mathrm{kg}$ for beta/gamma emitters with half-lives of greater than one year and less than $3 \mathrm{TBq} / \mathrm{kg}$ for ${ }^{3} \mathrm{H}$ and beta/ gamma emitters with half-lives of one year or less (IAEA 1986), packed in metal containers (such as paper and textiles, resins, filters, etc., solidified with cement or bitumen) were dumped in the northeast Atlantic and Northwest Pacific sites, however, full reactor assemblies with spent nuclear fuel were dumped in the arctic Kara Sea and reactor assemblies without fuel were dumped in the Japan Sea/East Sea. Radioactive wastes were also released as liquids, mainly in the Barents Sea and in the Japan Sea/East Sea as late as 1993. As a result of the London Convention of 1972, dumping radioactive wastes in the sea was banned, although dumping continued in some areas.

We shall discuss in detail the dumping sites in the northwest Pacific Ocean where radioactive wastes, which included $457 \mathrm{TBq}$ of liquid radioactive wastes and $418 \mathrm{TBq}$ of solid wastes, have been dumped over the last three decades, chiefly by the former Soviet Union and the Russian Federation. Major dumping of $401 \mathrm{TBq}$ of liquid wastes was carried out mainly in 1986 in the north central Japan Sea/East Sea (in the rectangle $41^{\circ} 36^{\prime} \mathrm{N}, 133^{\circ} 42^{\prime} \mathrm{E}$, and $41^{\circ} 46^{\prime} \mathrm{N}, 134^{\circ} 42^{\prime} \mathrm{E}$ ). Liquid radioactive wastes dumped in 1992 were about $0.5 \mathrm{TBq}$ in the Japan Sea/East Sea and about $0.5 \mathrm{TBq}$ east of Kamchatka. The contribution from 1993 dumping in the Japan Sea/East Sea was only about 0.01 TBq. The major dumping areas for solid radioactive wastes were in the Japan Sea/East Sea (in the rectangle $40^{\circ} 10^{\prime} \mathrm{N}, 131^{\circ} 15^{\prime} \mathrm{E}$, and $41^{\circ} 55^{\prime} \mathrm{N}, 134^{\circ} 42^{\prime} \mathrm{E}$ ) which contains about $307 \mathrm{TBq}$ of wastes dumped mostly between 1971 and 1988. The dumping area east of Kamchatka (in the rectangle $52^{\circ} 28^{\prime} \mathrm{N}, 159^{\circ} 06^{\prime} \mathrm{E}$, and $52^{\circ} 34^{\prime} \mathrm{N}, 159^{\circ} 11^{\prime} \mathrm{E}$ ) contains about $111 \mathrm{TBq}$ of solid radioactive wastes dumped mostly between 1971 and 1989. Japan dumped $15.1 \mathrm{TBq}$ of solid wastes in the western North Pacific (east of Tokyo) and the Republic of Korea dumped solid wastes with $0.1-46 \mathrm{mR} / \mathrm{h}$ surface dose rate in the Japan Sea/East Sea (IAEA 1999).

\footnotetext{
${ }^{1}$ International Atomic Energy Agency, Marine Environmental Laboratory, 4 Quai Antoine 1er, MC-98012, Monaco. Email: p.povinec@iaea.org.

${ }^{2}$ The University of Arizona, NSF Arizona AMS Facility, Department of Physics, Tucson, Arizona 85721, USA
}

(C) 2001 by the Arizona Board of Regents on behalf of the University of Arizona Radiocarbon, Vol 43, Nr 2B, 2001, p 879-886

Proceedings of the 17 th International ${ }^{14} \mathrm{C}$ Conference, edited by I Carmi and E Boaretto 
${ }^{14} \mathrm{C}$ formed an important part of the beta-activity of the dumped wastes, therefore, in areas where low-level wastes had been dumped, it could have a greater impact on ${ }^{14} \mathrm{C}$ concentration in seawater than global fallout (if leakage from dumped containers occurred). Because of its long half-life, ${ }^{14} \mathrm{C}$ will be the main constituent in possible leakages from the wastes in the future and the main source of radiation doses from marine food which will be delivered to humans. The high analytical sensitivity offered by accelerator mass spectrometry (AMS) enables to find even tracer amounts of ${ }^{14} \mathrm{C}$ in the marine environment, which could be related to a leakage from dumped wastes. It is expected that after tens of years lying on the sea-bed, metal containers containing wastes will corrode and radionuclides will be released from the wastes into seawater.

For many years the IAEA's Marine Environment Laboratory (IAEA-MEL) has been engaged in an assessment program related to radioactive waste dumping and has participated in several expeditions to the Atlantic, Arctic and Pacific Oceans to sample seawater, biota and sediment. In the present paper, we discuss ${ }^{14} \mathrm{C}$ results obtained for the northeast Atlantic and the Northwest Pacific Oceans.

\section{METHODS}

During seawater sampling, precautionary measures were taken to drive out air to avoid its mixing with the water. Mercury chloride was added to poison the water in the bottle and prevent any biological activity.

The dissolved inorganic carbon (DIC) was extracted in the laboratory by acidification of the water sample to $\mathrm{pH} 3$. The carbon dioxide released was then (in a flow of high-purity oxygen gas) collected in a trap cooled to liquid nitrogen temperature. The $\mathrm{CO}_{2}$ was then purified by passing through cryogenic traps to remove water. $\mathrm{Cu} / \mathrm{Ag}$ furnaces were used to remove nitrogen oxides and halogens. The stable isotopic composition of a split sample of the gas was measured in an Optima mass spectrometer. The $\mathrm{CO}_{2}$ was finally converted to graphite over an $\mathrm{Fe}$ catalyst. The adopted procedures have already been described (Donahue et al. 1990a). The ${ }^{14} \mathrm{C}$ activity in seawater samples is expressed by $\Delta^{14} \mathrm{C}$ (Donahue et al. 1990b).

${ }^{3} \mathrm{H}$ measurements of seawater samples were carried out by the Institute of Geological and Nuclear Sciences, Lower Hutt (New Zealand) using electrolytical enrichment and liquid scintillation spectrometry. The results are expressed in Tritium Units (TU) (1 TU is a ratio of one ${ }^{3} \mathrm{H}$ atom to $10^{18}$ hydrogen $\left({ }^{1} \mathrm{H}\right)$ atoms, equal to $114 \mathrm{mBq} / \mathrm{L}$ of water).

\section{RESULTS AND DISCUSSION}

\section{The Northeast Atlantic Ocean}

The northeast Atlantic dumping sites have been surveyed periodically since 1977 by OECD/NEA member states. However, the final CRESP (Coordinated Research and Environmental Surveillance Programme) project report did not contain results on ${ }^{14} \mathrm{C}$ levels in the water column at dump sites (NEA 1996). Small leakages were reported for ${ }^{3} \mathrm{H},{ }^{90} \mathrm{Sr}$ and ${ }^{137} \mathrm{Cs}$ radionuclides.

In 1992, IAEA-MEL, in collaboration with the Fisheries Laboratory of the Ministry of Agriculture, Fisheries and Food (UK), participated in a cruise organized by the Bundesforschungsanstalt für Fischerei (BFA), Germany. Measurable leakages were found for ${ }^{14} \mathrm{C}$ and other radionuclides from dumped radioactive wastes, but had a negligible radiological impact (Baxter et al. 1995).

We discuss here only the results obtained on seawater samples collected in a cruise organized from 10 August to 13 September 1996 by the Bundesforschungsanstalt für Fischerei, Hamburg, Germany. 
Station B1 $\left(46^{\circ} 05^{\prime} \mathrm{N} ; 17^{\circ} 10^{\prime} \mathrm{W}\right)$ is in the western part of the largest northeast Atlantic dumping area situated in the rectangle $45^{\circ} 50^{\prime} \mathrm{N}, 16^{\circ} 00^{\prime} \mathrm{W}$ and $46^{\circ} 10^{\prime} \mathrm{N}, 17^{\circ} 30^{\prime} \mathrm{W}$, where major wastes (about 30 $\mathrm{PBq}$ ) were dumped between 1973 and 1982 by OECD/NEA Member States.

The $\Delta^{14} \mathrm{C}$ profile in the water column of samples taken at this site is depicted in Figure 1. A remarkable peak was observed at medium depths between 2000 and $3000 \mathrm{~m}$. A higher ${ }^{14} \mathrm{C}$ value was found in the bottom sample as well. As expected, a similar profile was obtained for ${ }^{3} \mathrm{H}$, which is also shown in Figure 1.

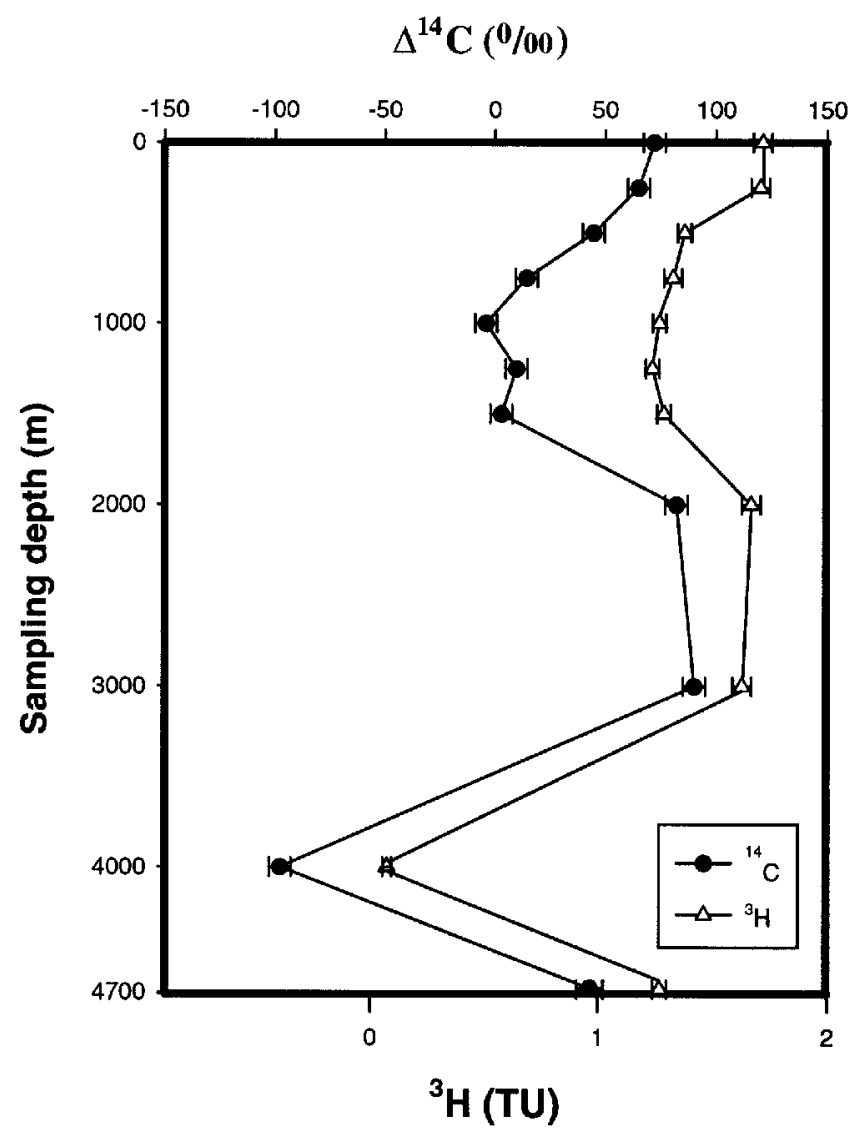

Figure $1 \Delta^{14} \mathrm{C}$ and ${ }^{3} \mathrm{H}$ water profiles in the northeast Atlantic Ocean (St. B1 sampled in $1996\left[\left(46^{\circ} 05^{\prime} \mathrm{N} ; 1^{\circ} 10^{\prime} \mathrm{W}\right)\right]$, bottom depth $\left.4700 \mathrm{~m}\right)$.

The persistence of a minimum of ${ }^{14} \mathrm{C}$ and ${ }^{3} \mathrm{H}$ data for northeast Atlantic waters at around $1000 \mathrm{~m}$ depth is visible in GEOSECS (Östlund et al. 1974) and TTO (Östlund et al. 1990) data as well, although the maxima (between 2000 and $3000 \mathrm{~m}$ depth) reported in Figure 1 are much higher and comparable to surface levels.

However, such clear medium depth maxima were not observed in TTO data for the northeast Atlantic (Östlund et al, 1990) (there were no GEOSECS stations in the northeast Atlantic Ocean). Data 
from the METEOR 1981 cruise to the northeast Atlantic (Schlitzer, 1986) did not show values for depths above $2500 \mathrm{~m}$ and therefore, a complete comparison is not possible.

It is a known fact that the high latitude North Atlantic areas (north of $42^{\circ} \mathrm{N}$ ), which coincide with the water mass formation areas of the North Atlantic Deep Waters (NADW), are an important sink for atmospheric $\mathrm{CO}_{2}$ (Broecker and Peng 1992; Takahashi et al. 1995). High latitude injection processes must therefore be responsible for the observed evolution of $\Delta^{14} \mathrm{C}$ and ${ }^{3} \mathrm{H}$ concentrations below 1000 $\mathrm{m}$, downwelling high surface radionuclide concentrations to medium depths. This subduction mode water regime, when water masses labeled by global fallout are transported from the surface to medium depths has also been observed for ${ }^{90} \mathrm{Sr}$ and ${ }^{137} \mathrm{Cs}$ radionuclides (Povinec et al. in preparation). Surface waters may be directly transported into the deep interior of the Atlantic via conveyor circulation (Broecker 1991), also known as thermohaline circulation (Keeling and Peng 1995). The present observations confirm this hypothesis.

The $\Delta^{14} \mathrm{C}$ increase observed in the bottom sample is not yet well understood. Higher concentrations in the bottom sample were also observed for ${ }^{3} \mathrm{H},{ }^{90} \mathrm{Sr}$ and ${ }^{137} \mathrm{Cs}$, however, not for ${ }^{239,240} \mathrm{Pu}$ (Povinec et al. in preparation). It is possible that higher radionuclide concentrations observed near the sea bed are also a result of the transport of North Atlantic global fallout labeled waters to bottom depths (Nyffler et al. 1996). However, higher bottom $\Delta^{14} \mathrm{C}$ values were not observed in TTO (Östlund et al 1990) and METEOR 1981 data (Schlitzer 1986). At the present stage of investigations, therefore, we cannot rule out possible leakage from dumped radioactive wastes as well. As we have only measured this profile, more samples have to be analyzed, from both dumping sites and background stations before final conclusions can be made on possible ${ }^{14} \mathrm{C}$ leakages from the dumping site visited.

\section{The Northwest Pacific Ocean}

IAEA-MEL participated in two expeditions organized in 1994 and 1995 under the Japanese-Republic of Korea-Russian Federation collaboration to sample seawater, biota and sediment in the Japan Sea/East Sea, the Sea of Okhotsk and the northwest Pacific Ocean (Hirose et al. 1999; Ikeuchi et al. 1999; Pettersson et al. 1999). In 1997 a special expedition (IAEA'97) was organized by IAEA-MEL to sample seawater, biota, and sediment from the sea area near Tokyo to the Hawaiian Islands, down to the Marshall Islands and back to Tokyo (Povinec and Togawa 1999).

The $\Delta^{14} \mathrm{C}$ results in surface and bottom water samples collected at radioactive waste dumping areas and at background stations, are shown in Figure 2. In the Japan Sea/East Sea, elevated $\Delta^{14} \mathrm{C}$ values were observed both in surface and bottom waters $(2100 \mathrm{~m})$ at the Korean dumping site (Station K1). However, the analysis of other radionuclides $\left({ }^{3} \mathrm{H},{ }^{90} \mathrm{Sr},{ }^{137} \mathrm{Cs}\right.$ and $\left.{ }^{239,240} \mathrm{Pu}\right)$ did not show any elevations (Hirose et al. 1999; Ikeuchi et al. 1999). Actually, this is expected to be a small dumping area east of South Korea $\left(37^{\circ} 20^{\prime} \mathrm{N}, 130^{\circ} 44^{\prime} \mathrm{E}\right)$ where 115 containers of a total weight of $45 \mathrm{t}$ were dumped between 1968 and 1972 by the Republic of Korea (information on the total activity is missing).

A high ${ }^{14} \mathrm{C}$ value $(150 \%$ ) was obtained for the surface water sample collected at the Japanese dumping site east of Tokyo (Station J3; Figure 2). The bottom sample was taken at $1100 \mathrm{~m}$ water depth and showed a ${ }^{14} \mathrm{C}$ value of $-140 \%$ o which is about $80 \%$ higher than expected at this water depth, as derived from the closest station S1, visited during the IAEA 1997 expedition (Aramaki et al. 2000).

In the Sea of Okhotsk, the observed $\Delta^{14} \mathrm{C}$ values were as expected for given depths. As the sea is relatively shallow (bottom depths of Station R3 at the dumping area and background stations R2 and B1 were $1240 \mathrm{~m}, 116 \mathrm{~m}$, and $1340 \mathrm{~m}$, respectively), the corresponding ${ }^{14} \mathrm{C}$ values measured in bottom samples were higher in comparison to deep water samples collected in the Northwest Pacific Ocean. 


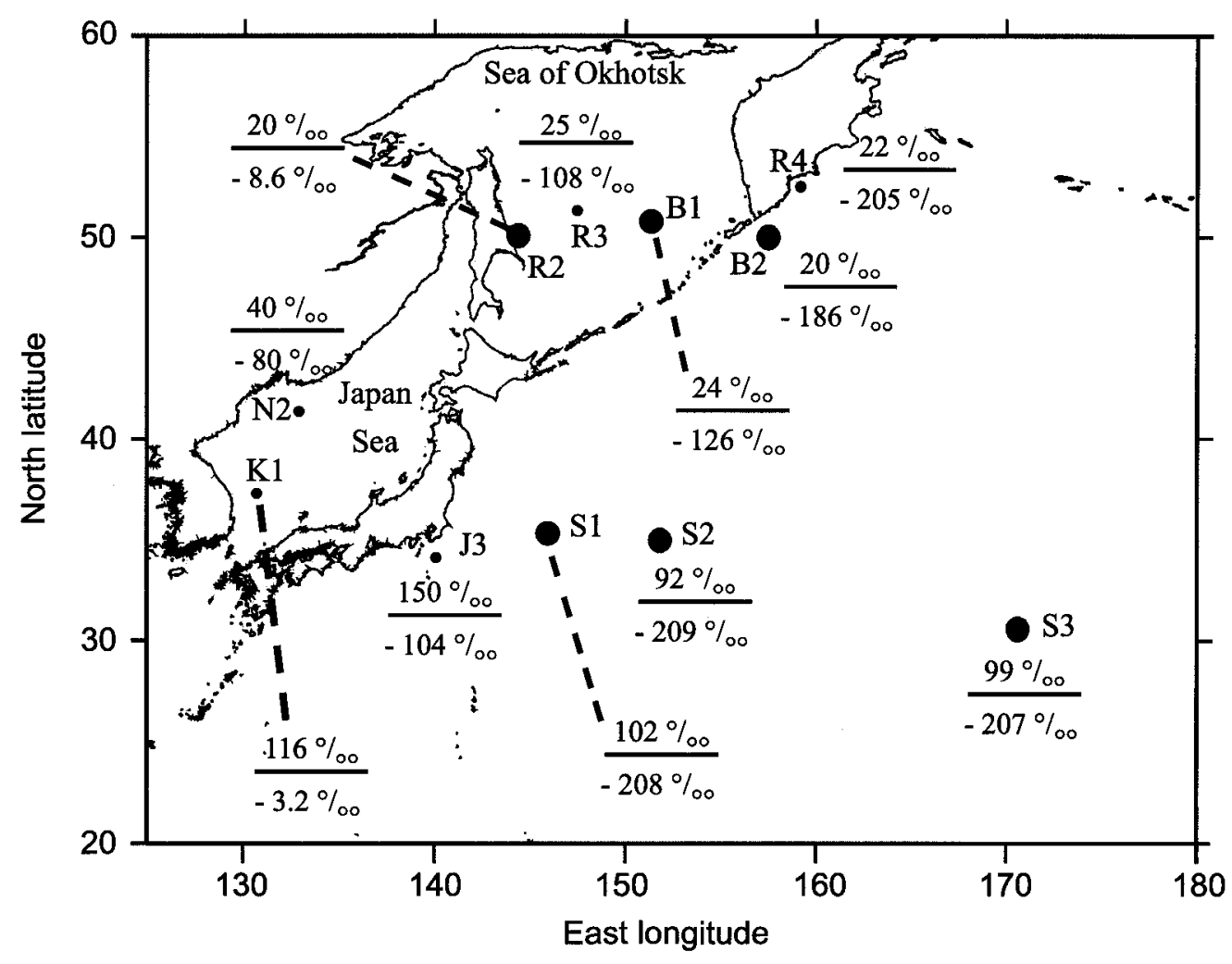

Figure $2 \Delta^{14} \mathrm{C}(\% \circ)$ in surface/bottom waters of the northwest Pacific Ocean. The stations at dumping sites are shown by small dots (stations N2, K1, J3, R3, and R4). The other stations shown as large dots are background sites.

$\Delta^{14} \mathrm{C}$ water profiles down to $3500 \mathrm{~m}$ obtained for Station N2 (sampled in 1994) in the central Japan Sea/East Sea and for Station R4 (sampled in 1995), east of Kamchatka (bottom depth $2245 \mathrm{~m}$ ), are shown in Figure 3. There are clear differences between these two profiles, also supported by ${ }^{3} \mathrm{H}$ results shown in the same figure (as well as by other anthropogenic radionuclides like ${ }^{90} \mathrm{Sr}$ and ${ }^{137} \mathrm{Cs}$, [Hirose et al. 1999]). Penetration of ${ }^{14} \mathrm{C}$ (and other radionuclides) in bottom waters of the Japan Sea/ East Sea (as opposed to the Northwest Pacific profile shown in the same figure) implies large-scale vertical mixing due to winter forcing in the north central Japan Sea/East Sea (Seung and Yoon 1995; Hirose et al. 1999), which controls the distribution of radionuclides in the Sea.

$\Delta{ }^{14} \mathrm{C}$ values down to $3500 \mathrm{~m}$ obtained for Station $\mathrm{N} 2$ located in the major dumping area of the central Japan Sea/East Sea are as expected: the surface ${ }^{14} \mathrm{C}$ values are below $50 \%$ and at a depth of 2100 $\mathrm{m}$ about $-80 \%$. However, both surface $\left(116 \%\right.$ ) and bottom $(-3.2 \% \circ) \Delta^{14} \mathrm{C}$ values observed at the Korean dumping site are much higher. Unfortunately, there are only a few measurements of ${ }^{14} \mathrm{C}$ in seawater available for the Japan Sea/East Sea. Tsunogai et al. (1993) reported $\Delta^{14} C$ measurements in water profile samples collected in 1988 in the central Japan Sea/East Sea which showed similar results to those presented in Figure 3. Therefore, more ${ }^{14} \mathrm{C}$ analyses are necessary before final conclusions can be made on possible leakage of ${ }^{14} \mathrm{C}$ from this dumping site. 


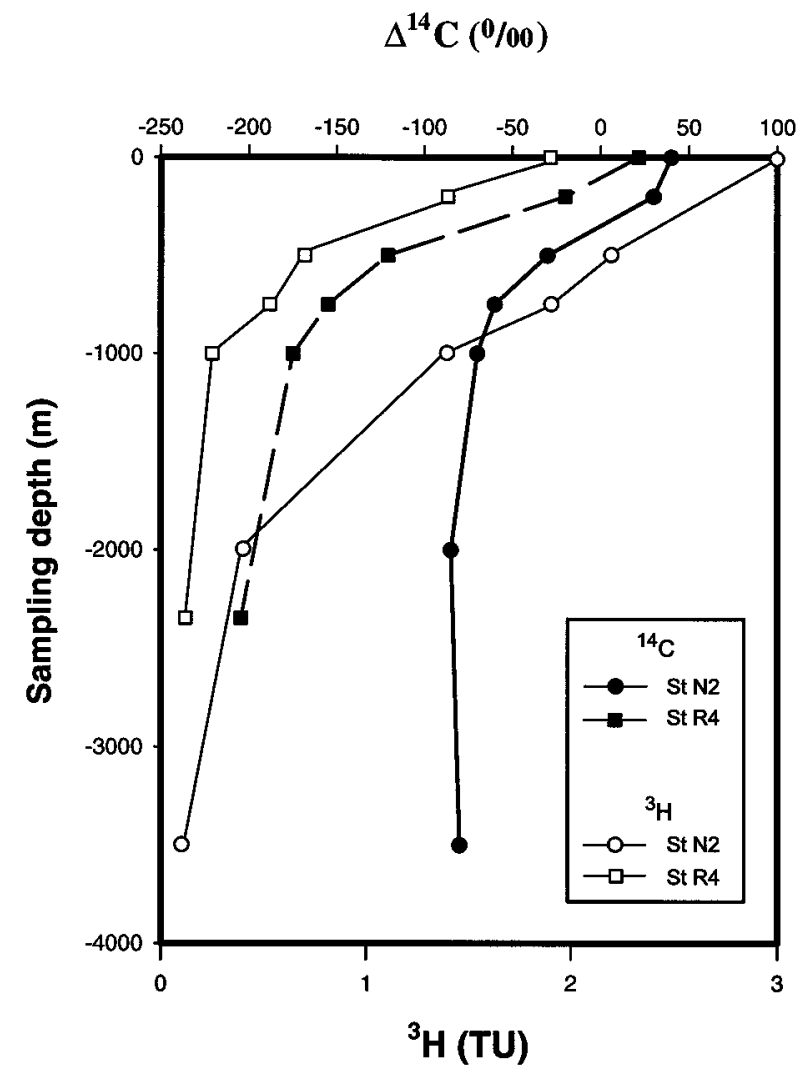

Figure $3 \quad \Delta^{14} \mathrm{C}$ and ${ }^{3} \mathrm{H}$ water profiles in the Japan Sea/East Sea (St. N2 [(41 $\left.\left.40^{\circ} \mathrm{N} ; 133^{\circ} 51^{\prime} \mathrm{E}\right)\right]$, bottom depth $\left.3500 \mathrm{~m}\right)$ and in the northwest Pacific Ocean (St. R4 [(52 $\left.\left.30^{\prime} \mathrm{N} ; 159^{\circ} 10^{\prime} \mathrm{E}\right)\right]$, bottom depth $\left.2360 \mathrm{~m}\right)$.

The surface and bottom $\Delta^{14} \mathrm{C}$ values obtained for stations east of Kamchatka (Figure 2) are as expected for the open ocean. The ${ }^{14} \mathrm{C}$ profile measured at Station R4 (Figure 3) is comparable to the background station B2, situated south of Kamchatka (bottom depth 1900 m).

Several other deep water profiles (up to depths of $6500 \mathrm{~m}$ ), taken during the IAEA'97 expedition to the Northwest Pacific Ocean (the surface and bottom ${ }^{14} \mathrm{C}$ values are depicted in Figure 2 for Stations $\mathrm{S} 1, \mathrm{~S} 2$, and S3), show typical behavior with a rapid decrease of ${ }^{14} \mathrm{C}$ values to depths of $500-1000 \mathrm{~m}$ (Jull et al. 1999; Amaraki et al. 2000). IAEA' $97{ }^{14} \mathrm{C}$ profiles are also similar to those observed during the WOCE program (Key 1996). In all cases the surface $\Delta{ }^{14} \mathrm{C}$ concentrations reported for the Northwest Pacific Ocean were below $110 \%$.

\section{CONCLUSIONS}

${ }^{14} \mathrm{C}$ measurements in seawater samples collected at former northeast Atlantic and Northwest Pacific Ocean radioactive waste dumping sites confirmed that it is possible to observe very small changes in ${ }^{14} \mathrm{C}$ concentrations with depth which could be caused either by specific mixing and transport processes observed in the water column or by small leakages from dumped containers. Therefore, such measurements, could give valuable information on the present status of the protection barriers of 
dumped containers. The small increases in ${ }^{14} \mathrm{C}$ concentrations observed in some bottom and surface seawater samples collected at the northwest Pacific Ocean dumping sites require further ${ }^{14} \mathrm{C}$ analyses before final conclusions can be made on possible leakage of ${ }^{14} \mathrm{C}$ from the visited dumping sites.

\section{ACKNOWLEDGMENTS}

The authors are indebted to the German, Japanese, Korean (Republic of), and Russian Governments for their various invitations and support of IAEA-MEL in the participation in international investigatory cruises. The authors are also indebted to their colleagues at IAEA-MEL and from collaborating institutes who participated in the sampling missions. The high precision ${ }^{3} \mathrm{H}$ analysis work done by Drs C Taylor and U Morgenstern (Institute of Geological and Nuclear Sciences in Lower Hutt, New Zealand) is highly acknowledged. The work presented here was partially supported by the Science and Technology Agency of Japan. IAEA-MEL operates under a bilateral agreement between the IAEA and the Government of the Principality of Monaco.

\section{REFERENCES}

Aramaki T, Mishizuma T, Kuji T, Povinec PP, Togawa O. 2000. Distribution of radiocarbon in the southwestern North Pacific. Radiocarbon. This issue.

Baxter MS, Ballestra S, Gastaud J, Hamilton TF, Harms I, Huynh-Ngoc L, Liong Wee Kwong L, Osvath I, Parsi P, Pettersson H, Povinec PP, Sanchez A. 1995. Marine radioactivity studies in the vicinity of sites with potential radionuclide releases. In: Environmental Impact of Radioactive Releases, Proceedings of an International Symposium on Environmental Impact of Radioactive Releases IAEA, Vienna, 8-12 May 1995. International Atomic Energy Agency, Vienna:125142.

Broecker WS. 1991. The great ocean conveyor. Oceanography 4:79-89.

Broecker WS, Peng TH. 1992. Interhemispheric transport of carbon dioxide by ocean circulation. Nature 356:587-589.

Donahue DJ, Linick TW, Jull AJT. 1990a. Isotope-ratio and background corrections for accelerator mass spectrometry radiocarbon measurements. Radiocarbon 32(2):135-142.

Donahue DJ, Jull AJT, Toolin LJ. 1990b. Radiocarbon measurements at the University of Arizona AMS Facility. Nuclear Instruments and Methods in Physics Research B52:224-228.

Hirose K, Amano H, Baxter MS, Chaykovskaya E, Chumichev VB, Hong GH, Isogai K, Kim CK, Kim SH, Miyao T, Morimoto, T, Nikitin A, Oda K, Pettersson HBL, Povinec PP, Seto Y, Tkalin A, Togawa O, Veletova NK. 1999. Anthropogenic radionuclides in seawater in the East Sea/Japan Sea: Results of the firststage Japanese-Korean-Russian expedition. Journal of Environmental Radioactivity 43:1-13.

IAEA. 1986. Definition and recommendations for the convention on the prevention of marine pollution by dumping of wastes and other matter. IAEA Safety Series 78 . Vienna: International Atomic Energy Agency.

IAEA. 1999. Inventory of radioactive waste disposals at sea. IAEA-TECDOC-1105. Vienna: International Atomic Energy Agency

Ikeuchi Y, Amano H, Aoyama M, Berezhnov VI, Chaykovskaya E, Chumichev VB, Chung CS, Gastaud J, Hirose $\mathrm{K}$, Hong $\mathrm{GH}$, Kim CK, Kim SH, Miyao T, Morimoto T, Nikitin A, Oda K, Pettersson HBL, Povinec PP, Tkalin A, Togawa O, Veletova NK. 1999. Anthropogenic radionuclides in seawater of the Far Eastern Seas. The Science of the Total Environment 237/ 238:203-212.

Jull AJT, Burr GS, Courtney C, Povinec PP, Togawa O. 1999. Measurements of radiocarbon in the NW Pacific Ocean and its marginal seas. Proceedings of the International Symposium on Marine Pollution, Monaco, oct. 5-9, 1998 IAEA-TECDOC-1094, Vienna, Austria:249-253.

Keeling RF, Peng TH. 1991. Transport of heat, $\mathrm{CO}_{2}$ and $\mathrm{O}_{2}$ by the Atlantic's thermohaline circulation. Philosophical Transactions of the Royal Society of London B 348:133-142.

Key RM. 1996. WOCE Pacific Ocean Radiocarbon Program. Radiocarbon 38(3):415-423.

NEA. 1996. Coordinated research and environmental surveillance programme related to sea disposal of radioactive waste. CRESP Final Report 1991-1995. Paris: OECD.

Nyffeler F, Cigna AA, Dahlgaard H, Livingston HD. 1996. Radionuclides in the Atlantic Ocean: A Survey. In: Radionuclides in the oceans inputs and inventory. Guéguéniat P, Germain P, Métivier H, coordinators. Institut de Protection et de Surete Nucleaire, Les Editions de Physique, FR, 29:1-28.

Östlund HG, Dorsey HG, Rooth CG. 1974. GEOSECS North Atlantic radiocarbon and tritium results. Earth Planetary and Science Letters 23:69-86.

Östlund HG, Rooth CGH. 1990. The North Atlantic tritium and radiocarbon transients 1972-1983. Journal of Geophysical Research 95 C11:20,147-20,165.

Pettersson HBL, Amano H, Berezhnov VI, Chayk- 
ovskaya E, Chumichev VB, Chung CS, Gastaud J, Hirose K, Hong GH, Kim CK, Kim SH, Lee SH, Morimoto T, Nikitin A, Oda K, Povinec PP, Suzuki E, Tkalin A, Togawa O, Veletova NK, Volkov Y, Yoshida K. 1999. Anthropogenic radionuclides in sediments in the NW Pacific Ocean and its marginal seas: results of the 1994-1995 Japanese-Korean-Russian expeditions. The Science of the Total Environment 237/238:21324.

Povinec PP, Togawa O. 1999. Marine radioactivity studies in World Oceans (MARS). Proceedings of the International Symposium on Marine Pollution, Monaco, Oct. 5-9, 1998 IAEA-TECDOC-1094, Vienna, Austria:262-68.

Schlitzer R. 1986. ${ }^{14} \mathrm{C}$ in the deep water of the East At- lantic. Radiocarbon 28 (2A):391-396.

Seung Y-H, Yoon J-H. 1995. Some features of winter convection in the Japan Sea. Journal of Oceanography 51:61-73.

Takahashi T, Takahashi TT, Sutherland SC. 1995. An assessment of the role of the North Atlantic as a $\mathrm{CO}_{2}$ sink. Philosophical Transactions of the Royal Society of London B348:143-152.

Tsunogai S, Watanabe YW, Harada K, Watanabe S, Saito S, Nakajima M. 1993. Dynamics of the Japan Sea deep waters studied with chemical and radiochemical tracers. In: Teramoto T, editor. Deep ocean circulation. physical and chemical aspects. London: Elsevier. 105-119. 